\title{
Investigation of resistance of Salmonella spp. isolated from products and raw material of animal origin (swine and poultry)to antibiotics and disinfectants
}

Investigação da resistência a antibióticos e a desinfetantes de Salmonella spp. isoladas em produtos e matéria-prima de origem animal (suínos e aves)

\author{
MACIEL, Mônica Jachetti ${ }^{1}$; MACHADO,Gustavo ${ }^{2}$; AVANCINI, Cesar Augusto Marchionatti ${ }^{3 *}$ \\ ${ }^{1}$ Universidade do Vale do Taquari, Centro de Ciências Biológicas e da Saúde, Lageado, Rio \\ Grande do Sul, Brasil. \\ https://orcid.org/0000-0002-6863-2181 \\ ${ }^{2}$ University of Minnesota, Veterinary Population Medicine, St. Paul, Minnesota, USA. \\ https://orcid.org/0000-0001-7552-6144 \\ ${ }^{3}$ Universidade Federal do Rio Grande do Sul, Departamento de Medicina Veterinária \\ Preventiva, Porto Alegre, Rio Grande do Sul, Brasil. \\ https://orcid.org/0000-0002-2404-2796
}

*Endereço para correspondência: cesar.avancini@ufrgs.br

\begin{abstract}
The genus Salmonella spp. Has worldwide geographical distribution, and represents a potential risk both to animal and human health. Inadequate use as well as continuous exposure to antibiotics and disinfectants might lead to the appearance of resistance of these microorganisms to antimicrobial compounds. The aims of this study were to investigate the occurrence of resistance in Salmonella spp., isolated from products and raw material of animal origin (swine and poultry), to antibiotics and disinfectants, and check whether the phenomenon of simultaneous resistance to disinfectants occurs among the antibiotic-resistant isolates. The test of susceptibility to antimicrobials (TSA) applied in 134 isolates indicated that $51(38 \%)$ were resistant to at least one of the eight antibiotics used, and 28 (55\%) of resistant isolates were multi-resistant. Resistant isolates were submitted to the test of quantitative suspension against four concentrations of disinfectants in three contact times, and the result was compared with that of the reference strain (Salmonella Choleraesuis ATCC 10.708). While the
\end{abstract}

reference strain was sensitive considering the highest concentration (200 ppm) and the lowest contact time (5 min) as indicators, $12(24 \%)$ isolates were resistant to cetyltrimethylammonium chloride (ammonia quaternary); the reference strain was resistant to chlorhexidine, which also occurred with $22(43 \%)$ of the isolates; similar to the reference strain, all isolates were sensitive/inactivated by sodium hypochlorite and iodophore. There were no significant relations of simultaneous resistance between the antibiotics and the disinfectants tested.

Keywords: antimicrobial resistance, simultaneous resistance, Salmonella

\section{RESUMO}

O gênero Salmonella spp. Possui distribuição geográfica mundial constituindo-se como potencial risco para a saúde animal e saúde humana. O uso inadequado bem como a exposição continuada aos antibióticos e aos desinfetantes pode resultar no surgimento de resistência desses microrganismos frente 
aos compostos antimicrobianos. Os objetivos do trabalho foram investigar a ocorrência de resistência a antibióticos e aos desinfetantes de Salmonella spp. isoladas em produtos e matéria-prima de origem animal (suínos e aves), e verificar se entre os isolados resistentes a antibióticos ocorre o fenômeno de resistência concomitante com desinfetantes. O teste de susceptibilidade a antimicrobianos (TSA) aplicado em 134 isolados indicou que 51 (38\%) foram resistentes a pelo menos um dos oito antibióticos usados, sendo que 28 (55\% dos resistentes) mostraram-se multirresistentes. Os isolados resistentes foram submetidos ao teste de suspensão quantitativo frente a quatro concentrações de desinfetantes em três tempos de contato, e o resultado comparado com o da cepa referência (Salmonella Choleraesuis ATCC 10.708). Considerando como indicador a maior concentração (200 ppm) e o menor tempo de contato ( $5 \mathrm{~min}$ ), frente ao cloreto de cetil trimetilamônio (quaternário de amônia), enquanto a cepa referência foi sensível, 12 (24\%) dos isolados foram resistentes; a cepa referência foi resistente a clorexidina, o que ocorreu com 22 (43\%) dos isolados; assim como ocorreu com a cepa referência, todos os isolados foram sensíveis/inativados pelo hipoclorito de sódio e iodóforo. Não houve relações estatisticamente significativas de resistência concomitante entre os antibióticos e os desinfetantes testados.

Palavras-chave:

resistência antimicrobiana, resistência concomitante, Salmonella 


\section{INTRODUCTION}

Bacteria of the genus Salmonella are widely distributed in Nature and might infect both birds and mammals, either wild or livestock, generally by fecaloral contamination, causing enteric, respiratory, and sepsis problems. Additionally, they cause losses with reduced performance, increased mortality, and increased costs with animal medications, which renders them both a sanitary and human health issue (MACHADO et al., 2016).

Salmonellosis is considered a zoonotic infection, where the transmission to humans generally occurs through the consumption of contaminated water or food of animal or plant origin. Even though it has a more active epidemiological notification than in Brazil, the United States has had a high frequency in the incidence of foodborne diseases (FBD), with an estimated 40,000 salmonellosis cases annually, of which $90 \%$ are foodborne, leading to five hundred deaths (SHINOHARA et al., 2008; MADIGAN et al., 2011; CDC, 2016). Due to damages caused to human and animal health, the World Health Organization (WHO) and the World Organization for Animal Health have encouraged countries to develop Salmonella spp. surveillance and control programs, along with fostering a global effort towards reducing the resistance of these bacteria to antimicrobials (WHO/FAO, 2000; BRASIL, 2012).

Antibiotics are used for the treatment of patients with bacterial diseases, as is the case of salmonellosis, and are routinely used in animal production as prophylaxis and as growth promoters. The wide use of antibiotics has increased the risk of developing resistance, which is a major concern as the classes of antibiotics for animals are the same used in humans (WHO, 2007; WHO, 2012). This resistance causes impacts in clinical and therapeutic procedures, and consequently, economic impacts (LOUREIRO et al., 2016). Furthermore, when salmonellosis attacks human beings it increases the permanence time of patients in the hospital environment, with risks of increasing the mortality of the individuals involved.

Disinfectants are used to act on microbial agents when they are freeliving organisms in the environment, and work as a sanitary procedure to protect susceptible hosts, reducing or eliminating potentially pathogenic microbial loads. Similar to antibiotics, studies alert that chemical products used to eliminate bacteria from the environment might be doing just the opposite. As bacteria are in constant contact with disinfectants in biosafety procedures for animal production and in sanitation protocols at food handling sites, they might develop resistance to disinfectants and even simultaneous resistance to antibiotics (CHAPMAN, 2003; GILBERT \& MCBAIN, 2003; HUET et al., 2008; EU, 2009; RIAZI \& MATTHEWS, 2011).

The occurrence of resistance might be caused by factors intrinsic to bacteria, with increased tolerance due to repeated exposure, or developed through genetic change. Likewise, there is evidence of the occurrence of crossresistance and co-resistance, when resistance to an antibacterial compound is followed by the appearance of resistance to another compound (BUFFET-BATAILLON et al., 2012; LAVILLA LERMA et al., 2015; 
SHAFAATI et al., 2016; TECHARUVICHIT et al., 2016).

The aims of this study were to investigate the susceptibility and resistance of Salmonella spp., isolated from foods of animal origin (swines and poultry), to antibiotics, investigate the susceptibility of resistant isolates to disinfectant compounds, and check whether among the antibiotic-resistant isolates the phenomenon of simultaneous resistance occurs with both antimicrobials (antibiotics and disinfectants).

\section{MATERIAL AND METHODS}

In the second half of 2013, 134 salmonellas were isolated from products of animal origin at a Laboratory of Food Microbiology, accredited by the Ministry of Agriculture, Livestock, and Food Supply (MAPA). Isolation and identification were performed according to the official methodology in Brazil (BRASIL, 2003). These products were of poultry and swine origin, e.g., frozen chicken and turkey carcass, skinless chicken breast, turkey cuts, mechanically recovered chicken meat (MRM), eggs, pork sausage, pig cheek and snout meat, mixed 'frescal' sausage, Tuscan sausage, cold cuts, cheese, and pork meal. Isolates of the same source-origin, i.e. potential clones, were avoided in the selection of isolates. After they were isolated, they were immediately frozen $\left(-20{ }^{\circ} \mathrm{C}\right)$ and kept in Eppendorfs containing BHI broth (Brain Heart Infusion- Oxoid ${ }^{\circledR}$, Michigan, United States) and glycerol (Hexis ${ }^{\circledR}$, São Paulo, Brazil).

Isolated salmonellas were submitted to a test of susceptibility to antimicrobials (TSA), following the agar diffusion disc technique described by CLSI (2008). The antibiotics (Laborclin ${ }^{\circledR}$, Paraná, Brazil) used were the following: amoxicillin $10 \mu \mathrm{g}$, ampicillin $10 \mu \mathrm{g}$, ceftiofur $30 \mu \mathrm{g}$, gentamicin $10 \mu \mathrm{g}$, enrofloxacin $5 \mu \mathrm{g}$, florfenicol $30 \mu \mathrm{g}$, tetracycline $30 \mu \mathrm{g}$, and sulfa-trimethoprim 1.25/23.75 $\mu \mathrm{g}$.

Antibiotic-resistant microorganisms $(n=51)$ were tested for susceptibility to the following chemical disinfectant compounds: cetyltrimethylammonium chloride (QAC - chemical group ammonia quaternary), chlorhexidine digluconate (C- chemical group biguanides), sodium hypochlorite ( $\mathrm{SH}$ chemical group halogens), and iodophore (I - chemical group halogens), all with technical reports provided by the distributing company of chemical products. Regarding the criteria for selecting the concentrations, as these are isolates from products and raw material of animal origin (and not from production or from animal health environments), they were defined according to the recommendation for use in meat and poultry handling environments (agro-industries, industrial kitchens) (SBCTA, 1995; GERMANO \& GERMANO, 2001; SCHMIDT, 2003; FDA, 2017).

The efficacy test of disinfectants was the Quantitative Suspension Test for Evaluating the Bactericidal Activity of Chemical Disinfectants and Antiseptics (phase 1) according to the protocol of the European Committee for Standardization (EN 1040:2005) (BRITISH STANDARD INSTITUTION, 2006; CHOJECKA et al., 2015).

Disinfectant concentrations were 200, 100,50 , and $25 \mathrm{ppm}$, and contact times were 5, 15, and 60 minutes. Initial inoculate population density was standardized using turbidity control of 
the 0.5 Mac Farland standard solution, which is the same as a suspension containing $10^{8} \mathrm{UFC} / \mathrm{mL}$. As neutralizer of disinfectant residues, we used a pool (BRITISH

STANDARD INSTITUTION, 2006) [(3\% polysorbate 80 (Synth $^{\circledR}$, São Paulo, Brazil); $0.3 \%$ soy lecithin (Delaware ${ }^{\circledR}$, Porto Alegre, Brazil), and $0.1 \%$ histidine (Synth ${ }^{\circledR}$, São Paulo, Brazil)]. We used XLD agar (Xylose Lysine Desoxycholate Agar) (Oxoid®, Michigan, United States) as control culture medium for potential handling contamination.

Results of disinfectant activity were expressed based on a comparison with the standard strain Salmonella Choleraesuis (ATCC 10,708). Bacteria were considered resistant $(\mathrm{R})$ when the logarithmic reduction of final population density compared to the initial density was lower than five logarithms. Isolates were classified as sensitive (S) when reduction was equal to or higher than five logarithms. This criterion was based on the protocol of the European Committee for Standardization, which determines that the initial population density of the reference strain must decrease by at least five logarithmic units after a certain period of contact (mandatory 5 minutes) for the efficacy of a disinfectant chemical compound to be proven. Converting the quantitative data obtained with the disinfectant test into dichotomous qualitative data was required to compare with antibiograms results.

Regarding the results of isolated salmonellas, the bacteria that had logarithmic reduction lower than the standard reference bacteria in the presence of disinfectant were considered resistant $(\mathrm{R})$, and those with reduction (microbiological effect) equal to or lower than the reference bacteria were considered sensitive (S). Microorganisms that were resistant to both antibiotic and disinfectant chemical compounds were considered to have simultaneous resistance.

Along with the descriptive presentation, an analysis of variance (ANOVA) and ttest were used to compare the results. Efficacy was not compared between disinfectants, but between the results of each variable (concentration and contact time) of each disinfectant. Critical Pvalues of $5 \%$ were considered as having significant difference. To evaluate simultaneous resistance between antibiotics and disinfectants, a test of concordance degree (Kappa) was used to compare the results of the isolates against antibiotics with each disinfectant compound at different concentrations and contact times. The test was performed using the $\mathrm{R}$ Software, v.2.15.2 ( $R$ Development Core Team, version 2012).

\section{RESULTS AND DISCUSSION}

Table 1 shows the distribution of resistance of Salmonella spp. isolates. Out of the 134 isolates (29 from swine products and 105 from poultry products), $51(38 \%)$ were resistant to at least one antibiotic. The selection of isolates avoided isolates from the same source (products and product handling), which provided greater assurance that results were not repeated i.e., that isolates did not have the same genetic origin.

Of the resistant isolates, $17 \quad(33 \%)$ derived from pork raw materials and 34 $(67 \%)$ derived from poultry. Bacteria showed predominant resistance to the group of penicillins (amoxicillin and 
ampicillin), to tetracycline, and to gentamicin (aminoglycoside group)

Pandini et al. (2014) observed the resistance profile of serum types of Salmonella spp. isolates in chicken broiler aviaries and observed that, approximately $51 \%$ had resistance to one or more antimicrobials. In the present study, this percentage was the same $(51 \%)$; however, regarding the origin of isolates, $67 \%$ of this total derived from birds.

Table 1. Resistance (absolute and relative numbers) of the 51 Salmonella spp. isolates to the antibiotics tested

\begin{tabular}{cc}
\hline ANTIBIOTIC & RESISTANT (R) \\
\hline Amoxicillin & $39(76 \%)$ \\
Ampicillin & $35(67 \%)$ \\
Ceftiofur & $18(35 \%)$ \\
Enrofloxacin & $3(6 \%)$ \\
Florfenicol & $6(12 \%)$ \\
Gentamycin & $23(45 \%)$ \\
Tetracycline & $39(76 \%)$ \\
Sulfa-trimethoprim & $06(12 \%)$ \\
\hline
\end{tabular}

18 isolates $(35 \%)$ were observed to be resistant to one class of antibiotics, 5 $(10 \%)$ were resistant to two, $9(18 \%)$ were resistant to three, $17(33 \%)$ were resistant to four, $1(2 \%)$ was resistant to five, and $1(2 \%)$ was resistant to six classes. Twenty-eight microorganisms $(55 \%)$ showed resistance to three or more classes of antibiotics, and were thus considered multiresistant. The expression "multiresistance" can be used when one microorganism exhibits resistance to three or more classes of antibiotic agents (SCHWARZ et al., 2010). One isolate was resistant to seven antibiotics (amoxicillin, ampicillin, enrofloxacin, florfenicol, gentamycin, tetracycline, and sulfatrimethoprim) and to six different classes (penicillin, cephalosporin, quinolone, aminoglycoside, amphenicol, tetracycline, trimethoprim, and reductase inhibitors). Of the multiresistant strains, 21 (75\%) were isolated from poultry products and seven $(25 \%)$ were isolated from swine products. These resistant salmonellas were isolated from chicken carcass (20$95 \%$ ), from mechanically restored meat (chicken MRM) (1-5\%), pork sausage (4- 58\%), pig snout (1-14\%), pig cheek (1- 14\%), and pork meal (1- 14\%). Gomes-Neves et al. (2014) found a similar result, i.e., approximately $26 \%$ of salmonellas isolated from pork were multiresistant.

Table 2 shows the results of disinfectant tests compared to the reference strain. Sodium hypochlorite and iodophore were observed to meet the requirement of reduction by five or more logarithms to define a disinfectant as effective (BRITISH STANDARD INSTITUTION, 2006), at all concentrations and contact times. Ammonia quaternary compounds did not meet this requirement only at the concentration of $25 \mathrm{ppm}$ at 5 minutes. On the other hand, chlorhexidine was not effective at any concentration at 5 minutes, or at 15 minutes with the lowest concentration. 
Table 2. Resistance (R) and susceptibility (S) of SalmonellaCholeraesuis ATCC 10.708 to four concentrations of disinfectants; cetyltrimethylammonium chloride (group of Ammonia-QAC Derivative Compounds), chlorhexidine (C), sodium hypochlorite (SH), and iodophore (I) at three contact times.

\begin{tabular}{cccccc}
$\begin{array}{c}\text { Concentration } \\
(\mathrm{ppm})\end{array}$ & $\begin{array}{c}\text { Contact time } \\
\text { (minutes) }\end{array}$ & QAC & $\mathrm{C}$ & $\mathrm{SH}$ & $\mathrm{I}$ \\
\hline 200 & 5 & $\mathrm{~S}$ & $\mathrm{R}$ & $\mathrm{S}$ & $\mathrm{S}$ \\
& 15 & $\mathrm{~S}$ & $\mathrm{~S}$ & $\mathrm{~S}$ & $\mathrm{~S}$ \\
& 60 & $\mathrm{~S}$ & $\mathrm{~S}$ & $\mathrm{~S}$ & $\mathrm{~S}$ \\
\hline 100 & 5 & $\mathrm{~S}$ & $\mathrm{R}$ & $\mathrm{S}$ & $\mathrm{S}$ \\
& 15 & $\mathrm{~S}$ & $\mathrm{~S}$ & $\mathrm{~S}$ & $\mathrm{~S}$ \\
& 60 & $\mathrm{~S}$ & $\mathrm{~S}$ & $\mathrm{~S}$ & $\mathrm{~S}$ \\
\hline 50 & 5 & $\mathrm{~S}$ & $\mathrm{R}$ & $\mathrm{S}$ & $\mathrm{S}$ \\
& 15 & $\mathrm{~S}$ & $\mathrm{~S}$ & $\mathrm{~S}$ & $\mathrm{~S}$ \\
& 60 & $\mathrm{~S}$ & $\mathrm{~S}$ & $\mathrm{~S}$ & $\mathrm{~S}$ \\
\hline 25 & 5 & $\mathrm{R}$ & $\mathrm{R}$ & $\mathrm{S}$ & $\mathrm{S}$ \\
& 15 & $\mathrm{~S}$ & $\mathrm{R}$ & $\mathrm{S}$ & $\mathrm{S}$ \\
& 60 & $\mathrm{~S}$ & $\mathrm{~S}$ & $\mathrm{~S}$ & $\mathrm{~S}$ \\
\hline
\end{tabular}

Considering the protocol of the European Committee for Standardization (CEN) (BRITISH STANDARD INSTITUTION, 2006), which describes the technique used against the reference strain, the ammonia quaternary compound, sodium hypochlorite, and iodophore were considered effective as disinfectants, except for the ammonia quaternary compound at the concentration and contact time mentioned above. On the other hand, chlorhexidine caused a reduction of 3 to $4 \operatorname{logs}$ within 5 minutes of contact at all concentrations.
Therefore, it did not meet the requirement set by $\mathrm{CEN}$ within this time.

Table 3 shows the results of the test of susceptibility to disinfectants of the 51 antibiotic-resistant Salmonella spp. isolates. Considering the variables 'concentration' and 'contact time', the analysis of variance showed that there was no significant difference between the resistance and susceptibility results of the isolates against each disinfectant compound. Therefore, the concentration to be used was not relevant. 
Table 3. Results, in absolute and relative numbers, of Salmonella spp. isolates $(\mathrm{n}=51)$ resistant to antibiotics and disinfectants cetyltrimethylammonium chloride (QAC), chlorhexidine (C), sodium hypochlorite ( $\mathrm{SH})$, and iodine (I), at different concentrations (ppm) and contact times (min.).

\begin{tabular}{|c|c|c|c|c|c|}
\hline $\begin{array}{l}\text { Concentration } \\
\quad(\mathrm{ppm})\end{array}$ & $\begin{array}{c}\text { Contact } \\
\text { Time (min.) }\end{array}$ & QAC & $\mathrm{C}$ & $\mathrm{SH}$ & I \\
\hline \multirow{3}{*}{200} & 5 & $12(24 \%)$ & $22(43 \%)$ & $0(0 \%)$ & $0(0 \%)$ \\
\hline & 15 & $4(8 \%)$ & $19(37 \%)$ & $0(0 \%)$ & $0(0 \%)$ \\
\hline & 60 & $3(6 \%)$ & $0(0 \%)$ & $0(0 \%)$ & $0(0 \%)$ \\
\hline \multirow{3}{*}{100} & 5 & $13(25 \%)$ & $27(53 \%)$ & $0(0 \%)$ & $0(0 \%)$ \\
\hline & 15 & $7(14 \%)$ & $17(33 \%)$ & $0(0 \%)$ & $0(0 \%)$ \\
\hline & 60 & $2(4 \%)$ & $2(4 \%)$ & $0(0 \%)$ & $0(0 \%)$ \\
\hline \multirow{3}{*}{50} & 5 & $29(57 \%)$ & $29(57 \%)$ & $1(2 \%)$ & $0(0 \%)$ \\
\hline & 15 & $17(33 \%)$ & $22(43 \%)$ & $0(0 \%)$ & $0(0 \%)$ \\
\hline & 60 & $5(10 \%)$ & $5(10 \%)$ & $0(0 \%)$ & $0(0 \%)$ \\
\hline \multirow{3}{*}{25} & 5 & $42(82 \%)$ & $31(61 \%)$ & $2(4 \%)$ & $2(4 \%)$ \\
\hline & 15 & $40(78 \%)$ & $17(33 \%)$ & $1(2 \%)$ & $1(2 \%)$ \\
\hline & 60 & $25(49 \%)$ & $17(33 \%)$ & 0 & $1(2 \%)$ \\
\hline
\end{tabular}

The test conducted with disinfectants from the group of halogens (sodium hypochlorite and iodophore) with resistant isolates had practically the same results as the reference strain, except for the two lowest concentrations of sodium hypochlorite and the lowest concentration of iodophore, with the latter having one non-activated isolate. Concerning the assay with ammonia quaternary and chlorhexidine, unlike the standard strain, several isolates did not show susceptibility, and many of them even remained viable at all concentrations of these disinfectants (except for chlorhexidine at $200 \mathrm{ppm}$ ). Given that the registration of commercial disinfectant products is performed having the activity against a standard strain as reference, this results alerts for the need for monitoring the antimicrobial activity in real-life sanitary problem situations 
(salmonellosis cases or outbreaks, for instance).

Braoudaki \& Hilton (2005) verified that the efficacy of disinfectants might be questionable in some circumstances, and that the reckless use of these chemical compounds is a potential concern. The more frequently bacteria are exposed to antimicrobial agents, the higher the risk of developing resistant strains. Although the concentration used of disinfectants is usually much higher than the minimum inhibitory concentration, they might easily be diluted at a sub-inhibitory conditions and increase the tolerance of microorganisms to disinfectants.

There is some scientific proof that antibiotic-resistant bacteria are significantly less susceptible to disinfectants. Molina-González et al. (2014) tested antibiotic-multiresistant Salmonella enterica strains against sodium hypochlorite at recommended dosages and sub-dosages, and concluded that there was decreased susceptibility of the cultures against the antibiotics tested. They also observed that the extensive use of disinfectants at sub-lethal concentrations might contribute with the appearance of antibiotic resistance in Salmonella enterica strains resistant to multiple drugs. In addition, that susceptibility depends on the bacterial strain and on the antibiotic group tested, and this phenomenon was also observed by Braoudaki \& Hilton (2005) and Condell et al. (2012). However, unlike previous studies, in the present study, a higher resistance to isolates of sodium hypochlorite was not observed when this chemical compound was tested against antibiotic-resistant Salmonella spp. even at the lowest concentrations of use, such as 50 and $25 \mathrm{ppm}$.
Russel (2002) had already indicated that laboratory studies have shown some level of association between tolerance to disinfectants and resistance to antibiotics. However, he argued that in vitro bacteria might develop resistance to disinfectants through changes in the outer membrane, which might indirectly increase resistance to antibiotics. However, even considering that the relation between use of disinfectants and selection of antibiotic-resistant bacteria is not conclusive, he considers that the selective pressure caused by continuous use of disinfectants, integrons that carry bacteria and cassette genes, which provide antibacterial resistance needs to be further investigated. Beier et al. (2011),for instance, performing the characterization of enteric Salmonella resistance isolated from turkey to antibiotics, disinfectants, and growthpromoters, did not observe crossedresistance between antibiotics and disinfectants.

Of the 134 Salmonella spp. isolates investigated in this study, 51 were observed to have resistance to at least one antibiotic tested, which corroborates the efforts proposed by international organizations (World Health Organization; World Organization for Animal Health) and national organizations (Ministry of Agriculture, Livestock, and Food Supply; National Agency of Sanitary Surveillance) for monitoring and controlling resistance to antibiotics.

Due to the occurrence and frequency with which antibiotic-resistant isolates evaluated in this study exhibited additional resistance to the disinfectants ammonia quaternary and chlorhexidine, in procedures of disinfection in biosafety and in disinfection of 
environments where products of animal origin are handled, it is recommended to have the use of these two chemical groups alternated. Based on the results obtained in this study, the most indicated disinfectants considering this

\section{REFERENCES}

BEIER, R.C.; ANDERSON, P.N.; HUME, M.E; POOLE, T.L.; DUKE, S.E.; CRIPPEN, T.L.; SHEFFIELD, C.L.; CALDWELL, D.J.; BYRD, J.A; ANDERSON, R.C.; NISBET, D.J. Characterization of Salmonella enterica isolates from turkeys in commercial processing plants for resistance to antibiotics, disinfectants, and a growth promoter. Foodborne Pathogens

Disease [online], n. 8, v. 5, p.:593-600, 2011.

BRASIL. Ministério da Agricultura, Pecuária e Abastecimento (MAPA), Secretaria de Defesa Agropecuária. Instrução Normativa $n^{0} 62$ de agosto de 2003. Oficializa os Métodos Analíticos Oficiais para Análises Microbiológicas para Controle de Produtos de Origem Animal e Água. Diário Oficial da União, Brasília, de 18 de setembro de 2003, 14-51 p.

BRASIL. Agência Nacional de Vigilância Sanitária (ANVISA).

Relatório de pesquisa em vigilância sanitária de alimentos: Monitoramento da prevalência e do perfil de suscetibilidade aos antimicrobianos em enterococos e salmonelas isoladas de carcaças de frango congeladas comercializadas no Brasil. Brasília, 2012. Disponível em: < http://portal.anvisa.gov.br/documents/3 problem situation are sodium hypochlorite and iodophore.

There were no significant relations of simultaneous resistance between the antibiotics and the disinfectants tested.

3916/395481/Relat\%25C3\%25B3rioPre baf-vers \%25C3\%25A3ofinalmar2012.pdf/f6bb5296-e633-4f7b-b81f48a99430da6a>. Accessed on: 18 mai. 2017.

BRAOUDAKI, M.; HILTON, A.C. Mechanisms of resistance in Salmonella enterica adapted to erythromycin, benzalkonium chloride and triclosan.

International Journal of Antimicrobial Agents[online], n. 25, v. 1, p.31-7, 2005.

\section{BRITISH STANDARDS INSTITUTION (BSI). European} Standard EN 1040:2005. Chemical disinfectants and antiseptics quantitative - suspencion test for the evaluation of basic bactericidal activity of chemical desinfectants and antiseptics: test method and requerements (phase 1). Brussels: European Committee for Standardization, 2006.

BUFFET-BATAILLON, S.; TATTEVIN, P.; BONNAUREMALLET, M. et al. Emergence of resistance to antibacterial agents: the role of quaternary ammonium compounds-a critical review.

International Journal of Antimicrobial Agents [online], n. 39, v. 5, p. 381- 9, 2012.

CENTERS FOR DISEASE CONTROL AND PREVENTION (CDC). 
Estimates of foodborne illness in the United States. CDC, 2016. Disponível em:

https://www.cdc.gov/foodborneburden/. Acesso em: 03 de jul de 2018.

CHAPMAN, J.S. Disinfectant resistance mechanisms, cross-resistance, and co-resistance. International Biodeterioration \& Biodegradation [online], v. 51, n. 4, p. 271-6, 2003.

CHOJECKA, A.; WIERCIŃSKA, O; RÖHM-RODOWALD, E.;

KANCLERSKI, K; JAKIMIAK, B.

Glucoprotamin antimicrobial activity against selected standard antibioticresistant bacteria and reference strains used in the assessment of disinfection efficacy. Roczniki Państwowego Zakładu Higieny [online], v. 66, n.3, 281-288, 2015.

\section{CLINICAL AND LABORATORY}

STANDARDS INSTITUTE (CLSI).

Performance standards for antimicrobial disk and dilution susceptibility tests for bacteria isolated from animals; Approved standard- Third edition. M31- A3. v. 28, n.8. Pennsylvania, USA, 2008.

CONDELL, O.; SHERIDAN, A.; POWER, K.A.; BONILLIASANTIAGO, R,; SERGEANT, K.; RENOUT, J.; BURGESS, C.; FANNING, S.; NALLY, J. Comparative proteomic analysis of Salmonella tolerance to the biocide active agent triclosan. Jounal of Proteome Research [online], v. 75, p. 4505-4519, 2012.

\section{EUROPEAN COMISSION (EU) -}

Scientific Committee on Emerging and Newly Identified Health Risks (SCENIHR). Assessment of the antibiotic resistance effects of biocides: antibiotic resistance effects of biocides. Brussels: European Comission, 2009. Disponível em: $<$ http://ec.europa.eu/health/ph_risk/com mittees/04_scenihr/docs/scenihr_o_021. pdf $>$. Accessed on: 10 nov. 2015.

\section{FOOD AND DRUGS}

ADMINISTRATION (FDA). CFR -

Code of Federal Regulations Title 21, Volume 3, 21CFR178.1010, PART 178 -- INDIRECT FOOD ADDITIVES: ADJUVANTS, PRODUCTION AIDS, AND SANITIZERS. Subpart B-Substances Utilized To Control the Growth of Microorganisms. Sec. 178.1010 Sanitizing solutions. Revised as of April 1, 2017.

Disponivelem $<$ https://www.accessdata.f da.gov/scripts/cdrh/cfdocs/cfcfr/cfrsearc h.cfm?fr $=178.1010>$

Acesso em 21 ago 2017.

GERMANO, P.M.; GERMANO, M.I.S. Princípios gerais de Higienização. In:

Higiene e vigilância sanitária de alimentos. São Paulo : Livraria Varela, 2001. Parte 25 - pag. 399 - 420. GOMES- NEVES, E.; ANTUNES, P.; MANAGEIRO, V.; GÄRTNER, F.; CANIÇA, M.; DA COSTA, J; M. C.; PEIXE, L. Clinically relevant multidrug resistant Salmonella enterica in swine and meat handlers at the abattoir.

Veterinary Microbiology [online], n.168, p. 229-233, 2014.

GILBERT, P.; MCBAIN, A.J. Potential impact of increased use of biocides in consumer products on prevalence of antibiotic resistance. Clinical Microbiology Reviews [online], n. 16, p. 189-208, 2003. 
HUET, A. A.; RAYGADA, J. L.; MENDIRATTA, K.; SEO, S.M.,; KAATZ, G.W. Multidrug efflux pump over expression in Staphylococcus aureus after single and multiple in vitro exposures to biocides and dyes.

Microbiology[online], n. 154, p. 31443153, 2008.

LAVILLA LERMA, L.; BENOMAR, N.; CASADO MUÑOZ, M. GÁLVEZ, A.; ABRIOUEL, H..Correlation between antibiotic and biocide resistance in mesophilic and psychrotrophic Pseudomonas spp. isolated from slaughterhouse surfaces throughout meat chain production. Food Microbiology [online], v. 51, p. 33-44, 2015.

LOUREIRO, R. J.; ROQUE, F.; RODRIGUES, A. T.; HEDEIROS, M. T.; RAMALHEIRAE, E. O uso de antibióticos e as resistências bacterianas: breves notas sobre a sua evolução. Revista Portuguesa de Saúde Pública[online], v. 34, n. 1, p. 77-84, 2016.

MACHADO, G.M.; MOURA, S.V.; TANISE PACHECO FORTES, T.P.; FELIX, S.R.; CLÁUDIO DIAS TIMM, C.D.; SILVA, É.F. Impacto da salmonelose na suinocultura e suas implicações em saúde pública.

Arquivos do Instituto

Bioliológico[online], v.83, 1-5, e0472014, 2016.

MADIGAN, M.T.; BUCKLEY, D.H.; STAHL, D.A..Microbiologia de

Brock. 12 ed. Porto Alegre: ArtMed, 2011. 1128 p.

MOLINA-GONZÁLEZ, D.; CALLEJA, C. A.; ALONSO-
HERMANDO, A.; CAPITA, R. Effect of sub lethal concentrations of biocides on the susceptibility to antibiotics of multi-drug resistant Salmonella enteric strains. Food Control[online], n. 40, p. 329-334, 2014.

PANDINI, J.A. PINTO, F. G. S.; MULLER, J. M.; WEBER, L.D.; MOURA, A.C. Ocorrência e perfil de resistência antimicrobiana de sorotipos de Salmonella spp. isolados de aviários do Paraná, Brasil. Arquivos do Instituto Bioliológico [online]., p. 1-6, 2014.

RIAZI, S.; MATTHEWS, K.R. Failure of foodborne pathogens to develop resistance to sanitizers following repeated exposure to common sanitizers. International

\section{Biodeterioration \& Biodegradation} [online], v. 65, n. 2, p. 374-378, 2011.

RUSSEL, A. D. Introduction of biocides into clinical practice and the impact on antibiotic-resistant bacteria. Journal of Applied Microbiology [online], n. 92, p. 121-135, 2002.

SCHMIDT, R.H. Basic elements of equipment cleaning and sanitizing in food processing and handling operations. University of Florida.

ExtensionDocument FS14. 2003.

Disponível em <

https://edis.ifas.ufl.edu/pdffiles/FS/F

S07700.pdf>. Acessoem 15042017.

SCHWARTZ, K.J. Salmonellosis. In: STRAW, B.E.; MENGELING, W.L.; D'ALLAIRE,. S.; TAYLOR, D.J.. Diseases of swine. 8.ed. Ames, Iowa: Iowa State University, p.535-551, 2000.

SCHWARZ, S.; SILLEY P.; SIMJEE, S.; WOODFORDS, N.; VAN 
DUIJKEREN, E.; JOHNSON A.P.;

GAASTRA, W. Assessing the antimicrobial susceptibility of bacteria obtained from animals. Journal of

Antimicrobial Chemotherapy [online], v. 65, n. 4, p. 601-604, 2010. SHAFAATI, M.; BOROUMAND, M.; NOWROOZI. J.; AMIRI, P.;

KAZEMIAN, H. Correlation Between qacE and qacE $\Delta 1$ Efflux Pump Genes, Antibiotic and Disinfectant Resistant Among Clinical Isolates of E.coli.

Recent Patents on Antiinfective Drug Discovery [online], v. 11, n. 2, p. 189195, 2016.

SHINOHARA, N.K.S.; BARROS, V.B., JIMENEZ, S.M.C.; MACHADO, E.C.L.; DUTRA, R.A.F.; FILHO, J.L.L. Salmonella spp., importante agente patogênico veiculado em alimentos. Ciência \& Saúde Coletiva [online], v. 5, n. 13, p.1675-1683, 2008.

SOCIEDADE BRASILEIRA DE CIÊNCIA E TECNOLOGIA DE ALIMENTOS (SBCTA). Manual de higiene e sanitização para empresas de alimentos - Série qualidade -

PROFIQUAL/SBCTA, 1995.

TECHARUVICHIT, P.; TAKAHASHI, H.; KUDA, T.; MIYA, S.;

KEERATIPIBUL, S.; KIMURA, B.. Adaptation of Campylobacter jejuni to biocides used in the food industry affects biofilm structure, adhesion strength, and cross-resistance to clinical antimicrobial compounds.

Biofoulin[online], n. 32, v. 7, p. 827-39, 2016.

UNGEMACH, F.R.; MÜLLERBAHRDT, D.; ABRAHAM, G. Guidelines for prudent use of antimicrobials and their implications on antibiotic usage in veterinary medicine. International Journal of Medical Microbiology [online], n. 296, p. 33-38, 2006.

WORLD HEALTH ORGANIZATION (WHO). Containing antimicrobial resistance. Geneva, Switzerland: WHO; 2005. (WHO Policy Perspectives on Medicines. Disponível em: $<$ http://www.who.int/management/anmi crobialresistance.pdf $>$. Acessado em 03 jul. 2018.

WORLD HEALTH ORGANIZATION (WHO). FOOD AND AGRICULTURE ORGANIZATION OF THE UNITED NATIONS (FAO). Global principles for the containment of antimicrobial resistance in animals intended for food. Geneva, Switzerland, 5-9 June 2000. Disponível em: < http://www.foodsafetynews.com/WHO CDS_CSR_APH_2000.4\%5B1\%5D.pdf $>$.Accessed on: 14 out. 2014.

\section{WORLD HEALTH ORGANIZATION} (WHO). Critically important antimicrobials for human medicine. Copenhagen, 29-31 May 2007. Disponível em: < http://www.who.int/foodborne_disease/r esistance/antimicrobials_human.pdf $>$. Accessed on: 14 out. 2014.

WORLD HEALTH ORGANIZATION (WHO). The evolving threat of antimicrobial resistance: options for action. Geneva, Switzerland, 2012. Disponível em: < http://apps.who.int/iris/bitstream/10665/ 44812/1/9789241503181_eng.pdf>. Accessed on: 30 jun. 2016. 